\title{
PENGARUH BIAYA OPERASIONAL DAN ARUS KAS PENDANAAN TERHADAP PROFITABILITAS PT. CITACONTRAC
}

\author{
Meliana ${ }^{1}$ \\ Fakultas Ekonomi Universitas Krisnadwipayana \\ Jalan Unkris Jatiwaringin Jakarta Timur \\ e-mail : meliyanajakarta21@gmail.com \\ Mulia Rahmah ${ }^{2}$ \\ Fakultas Ekonomi Universitas Krisnadwipayana \\ Jalan Unkris Jatiwaringin Jakarta Timur \\ e-mail : $\underline{\text { muliarahmah@gmail.com }}$
}

\begin{abstract}
To determine the effect of operating costs on profitability (Return On Assets), the effect of funding cash flows on profitability (Return On Assets), and the effect of operating costs and funding cash flows on profitability (Return On Assets). The research method used in the research is quantitative descriptive method. The results of this study indicate that operational costs do not affect profitability but have a positive relationship, while funding cash flows do not affect profitability but have a positive relationship. The conclusion of this study is that the increase in profitability cannot be measured in terms of operational costs and cash flow, but also as a whole, including from the performance of the organization. If the organization's performance is satisfactory, the company's profitability will increase, and vice versa will decrease. The suggestion of this research is that the independent variables used should not only be operational costs and cash flow because there are still many factors in the company that can affect profitability such as the management of receivables, debt management, and so forth.
\end{abstract}

Keywords : Operating Cost, Cash Flow Funding, Probability

\section{PENDAHULUAN}

Adanya persaingan antar perusahaan yang satu dengan yang lain baik perusahaan swasta maupun badan usaha milik negara (BUMN), akan memicu perusahaanperusahaan untuk meningkatkan pelayanan kepada konsumennya, oleh karena itu perusahaan dituntut untuk memperbaiki kinerja perusahaan secara menyeluruh.Sebagai salah satu perusahaan swasta PT. CITACONTRAC merupakan perusahaan yang bergerak dalam bidang jasa, menyadari bahwa perusahaan bergantung pada kepuasan pelanggan, yaitu Perusahaan Listrik Negara (PLN) dimana kualitas jasa itu sesuai dengan keinginan dan harapan Perusahaan Listrik Negara (PLN).

Untuk menjalankan semua kegiatan perusahaan dalam upaya mencapai tujuan yang diharapkan, diperlukan biaya operasional. Biaya Operasional merupakan salah satu elemen yang penting dalam upaya mempertahankan dan menghasilkan pendapatan. Biaya operasional merupakan biaya yang dipengaruhi oleh aktivitas perusahaan, sehingga semakin meningkat aktivitasnya, akan semakin meningkat pula biaya operasionalnya. Biaya operasional pada suatu perusahaan, termasuk PT. CITACONTRAC antara lain biaya gaji, biaya BBM, biaya Peralatan dan Perlengkapan Kantor.

Perolehan laba sangat ditentukan oleh pendapatan yang diperoleh dan biaya yang

Copyright (c) 2020 Mulia Rahmah, S. Kom., M.Si., Meliana Meliana 
JURNAL AKUNTANSI DAN BISNIS KRISNADWIPAYANA

Vol. 7 No. 2 (Mei - Agustus) 2020

dikeluarkan dalam rangka memperoleh pendapatan tersebut. Agar dapat mencapai laba yang maksimal pihak manajemen hanya dapat mengendalikan komponen biaya misalnya pada komponen biaya pelaksanaan proyek yang akan mempengaruhi pendapatan, Besarnya biaya tersebut sangat bergantung pada pencapaian target.

Return On Asset (ROA) merupakan salah satu indikator profitabilitas PT. CITACONTRAC yang digunakan untuk mengukur sejauh mana kemampuan suatu perusahaan untuk memperoleh laba, maka penulis menggunakan Return On Asset (ROA) sebagai indikator. Berdasarkan tabel tersebut menunjukkan adanya Return On Asset (ROA) mengalami penurunan dari tahun 2012 sampai 2014 sebaliknya biaya operasional mengalami peningkatan namun pada tahun 2012 Return On Asset (ROA) dan biaya operasional meningkat dibanding tahun 2011. Setiap perusahaan tidak luput dari kesenjangan transaksi keuangan yang terkait dengan penanganan proyek, kas dan pendapatan seperti adanya persentasi pencapaian invoice bulanan sesuai target apabila lebih dari target maka akan berdampak terhadap nilai invoice yang dihitung oleh Perusahaan Listrik Negara (PLN) dan juga Perusahaan Listrik Negara (PLN) memberikan waktu untuk menutup hasil invoice bulanan.

\section{LANDASAN TEORI}

\section{Biaya}

Berdasarkan (Mulyadi 2012) biaya adalah merupakan objek yang dicatat, digolongkan, diringkas dan disajikan oleh akuntansi biaya. Dalam arti luas biaya adalah pengorbanan sumber ekonomi yang di ukur dalam satuan uang, yang telah terjadi atau yang kemungkinan akan terjadi untuk tujuan tertentu. Penggolongan biaya umumnya ditentukan atas dasar tujuan yang hendak dicapai dengan penggolongan tersebut, karena dalam akuntansi biaya dikenal dengan konsep "different costs for different purposes".

\section{Biaya Operasional}

Berdasarkan periode nya (Hartoko 2011) pengertian Biaya Operasional adalah Biaya operasional merupakan seluruh biaya yang dikeluarkan dalam kurun waktu tertentu untuk mendapatkan atau membuat suatu barang.

\section{Arus Kas}

Menurut (Martani 2012) Arus kas adalah Laporan yang menyajikan suatu informasi tentang arus kas masuk dan arus kas keluar dan setara kas suatu entitas untuk suatu periode tertentu.

\section{Profitabilitas}

Menurut (Guinan 2010) profitabilitas adalah kelas metrik keuangan yang membantu bisnis untuk menghasilkan keuntungan dibandingkan dengan pengeluaran dan biaya relevan lainnya yang digunakan selama periode tertentu.

\section{METODE PENELITIAN}

Jenis data dalam penelitian ini adalah data sekunder, yaitu data yang telah tersedia. Studi Kepustakaan (Library Research) adalah dalam penelitian ini pengumpulan data dilakukan dengan cara membaca bukubuku, Artikel dan sumber data yang lainnya yang relavan dengan penelitian yang digunakan untuk mendukung penyajian teori

Copyright (c) 2020 Mulia Rahmah, S. Kom., M.Si., Meliana Meliana 
dan sebagai bahan pertimbangan. Studi Lapangan (Field Research) adalah Metode Observasi Dalam metode ini, diadakan observasi secara langsung pada objek yang diteliti. PT. CITACONTRAC. Metode Wawancara adalah Dalam metode ini dilakukan wawancara secara langsung dengan pihak yang terkait pada bagian keuangan yang digunakan untuk memperoleh klarifikasi tentang penyusunan anggaran dan pelaporan biaya operasional serta anggaran dan laporan arus kas pada PT. CITACONTRAC.

\section{HASIL PENELITIAN DAN PEMBAHASAN}

Analisis Biaya Operasional PT. CITACONTRAC Biaya operasional terdiri dari biaya langsung dan biaya tidak langsung. Biaya operasional yang besar karena penambahan jumlah tender diharapkan akan meningkatkan profitabilitas. Besarnya biaya operasional yang dikeluarkan PT. CITACONTRAC dapat mengurangi jumlah pendapatan sehingga profitabilitas atau laba semakin menurun. Dari data yang diperoleh gambaran biaya operasional pada PT. CITACONTRAC sebagai berikut :

Tabel 1. Biaya operasional

\begin{tabular}{|l|l|l|l|}
\hline $\begin{array}{l}\text { Tahu } \\
n\end{array}$ & $\begin{array}{l}\text { B.Operasion } \\
\text { al }\end{array}$ & $\begin{array}{l}\text { Perkembanga } \\
\text { n }\end{array}$ & $\begin{array}{l}\text { Pertumbuh } \\
\text { an }\end{array}$ \\
\hline 2010 & $\begin{array}{l}13,329,359,8 \\
89\end{array}$ & & - \\
\hline 2011 & $\begin{array}{l}14,077,031,3 \\
87\end{array}$ & $747,671,498$ & 5.61 \\
\hline 2012 & $\begin{array}{l}21,007,054,7 \\
56\end{array}$ & $6,930,023,36$ & 49.23 \\
& 9 & \\
\hline 2013 & $\begin{array}{l}16,140,712,1 \\
00\end{array}$ & $(4,866,342,6$ & \\
\hline
\end{tabular}

JURNAL AKUNTANSI DAN BISNIS KRISNADWIPAYANA

Vol. 7 No. 2 (Mei - Agustus) 2020

\begin{tabular}{|c|c|c|c|}
\hline & & 56) & \\
\hline 2014 & $\begin{array}{l}14,241,262,8 \\
96\end{array}$ & $\begin{array}{l}(1,899,449,2 \\
04)\end{array}$ & -11.77 \\
\hline 2015 & $\begin{array}{l}13,164,094,1 \\
05\end{array}$ & $\begin{array}{l}(1,077,168,7 \\
91)\end{array}$ & -7.56 \\
\hline 2016 & $\begin{array}{l}15,030,714,7 \\
59\end{array}$ & $\begin{array}{l}1,866,620,65 \\
4\end{array}$ & 14.18 \\
\hline 2017 & $\begin{array}{l}17,240,594,5 \\
35\end{array}$ & $\begin{array}{l}2,209,879,77 \\
6\end{array}$ & 14.70 \\
\hline Rata & rata & & 5.89 \\
\hline
\end{tabular}

Berdasarkan tabel diatas perkembangan tertinggi terjadi tahun 2012 yaitu sebesar 6.930.023.369 diperoleh dari biaya operasional tahun 2012 sebesar 21.007.054.756 dikurangi biaya operasional tahun 2011 sebesar 14.077.031.387 demikian pula pertumbuhan tertinggi terjadi pada tahun 2012 yaitu 49,23\% . Bila dilihat dari perkembangannya rata-rata biaya operasional yang dikeluarkan PT. CITACONTRAC selama tahun 2010-2017 masih menunjukkan angka kenaikan sebesar 5.89\% tersebut maka dapat dibuat grafik biaya operasional PT. CITACONTRAC

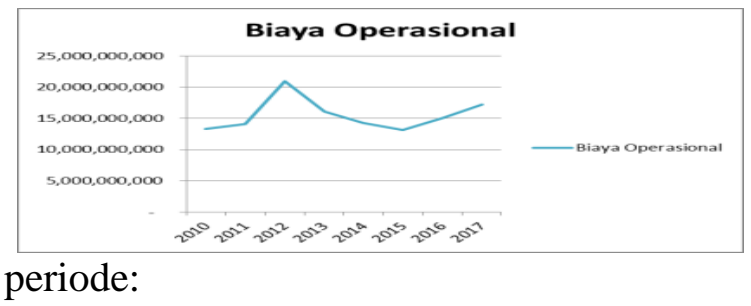

Gambar 1. Biaya operasional

Pada Grafik terlihat dengan jelas bahwa biaya operasional pada PT. CITACONTRAC rata-rata biaya operasional yang dikeluarkan masih menunjukkan angka penurunan semenjak tahun 2010 hingga tahun 2016. Penurunan biaya operasional paling tinggi terjadi pada tahun 2015 yaitu menurun sebesar Rp. 13.164.094.105 atau pertumbuhan sebesar minus $7,56 \%$ dari

Copyright (c) 2020 Mulia Rahmah, S. Kom., M.Si., Meliana Meliana 
tahun 2014. Hal tersebut dikarenakan oleh kecilnya pengeluaran pada biaya operasional PT. CITACONTRAC Hal ini disebabkan karena biaya administrasi proyek mengalami penurunan. adapun teorinya yaitu Menurut (Yusuf 2007) pengertian biaya operasi adalah sebagai berikut: "Biaya operasi atau biaya operasional adalah biaya-biaya yang tidak berhubungan langsung dengan produk perusahaan tetapi berkaitan dengan aktivitas operasi perusahaan sehari-hari". Sedangkan menurut (Jusuf 2007) menyatakan bahwa: "Bila perusahaan dapat menekan biaya operasi, maka perusahaan akan dapat meningkatkan laba, demikian juga sebaliknya, bila terjadi pemborosan biaya akan mengakibatkan menurunnya laba"

\section{Analisis Arus Kas Pendanaan PT. CITACONTRAC}

Aktivitas pendanaan adalah aktivitas yang mengakibatkan perubahan dalam jumlah serta komposisi ekuitas dan pinjaman perusahaan. Arus kas pendanaan berguna untuk memprediksi klaim terhadap arus kas masa depan oleh para pemasok modal perusahaan. Dari hasil penelitian diperoleh gambaran arus kas aktivitas pendanaan pada PT. CITACONTRAC sebagai berikut:

Tabel 2. Arus kas aktivitas pendanaan

\begin{tabular}{|l|l|l|l|}
\hline $\begin{array}{l}\text { Tah } \\
\text { un }\end{array}$ & $\begin{array}{l}\text { Arus Kas } \\
\text { Pendanaan(Ru } \\
\text { piah) }\end{array}$ & $\begin{array}{l}\text { PerkembangaPertumbu } \\
n \\
\text { han }\end{array}$ \\
\hline 2010 & $\begin{array}{l}14,461,956,88 \\
8\end{array}$ & - & - \\
\hline 2011 & $109,329,499,5$ \\
91 & $\begin{array}{l}94,867,542,7 \\
03\end{array}$ & 6.56 \\
\hline 2012 & $57,023,398,53$ & $\begin{array}{l}52,306,101, \\
6\end{array}$ & -0.48 \\
& $055)$ & \\
\hline 2013 & $285,794,231$ & $\begin{array}{l}(56,737,604, \\
305)\end{array}$ & -0.99 \\
\hline
\end{tabular}

JURNAL AKUNTANSI DAN BISNIS KRISNADWIPAYANA

Vol. 7 No. 2 (Mei - Agustus) 2020

\begin{tabular}{|c|c|c|c|}
\hline 2014 & $4165,192,374$ & $(120,601,857$ & -0.42 \\
\hline 2015 & $8,237,768,508$ & $8,072,576,13$ & 48.87 \\
\hline 2016 & & $\begin{array}{l}4 \\
(7,934,553,6 \\
67)\end{array}$ & -0.96 \\
\hline 2017 & $7442,642,290$ & $139,427,449$ & 0.46 \\
\hline
\end{tabular}

Berdasarkan tabel di atas perkembangan tertinggi terjadi tahun 2011 yaitu sebesar 94.867.542.703 diperoleh dari arus kas pendanaan tahun 2011 sebesar 109.329.499.591 dikurangi biaya operasional tahun 2010 sebesar 14.461.956.888 dan pertumbuhan tertinggi terjadi pada tahun 2015 yaitu $48,77 \%$ diperoleh dari perkembangan 2015 sebesar 8.072.576.134 dibagi dengan arus kas pendanaan tahun 2014 sebesar 165.192.374.

Bila dilihat dari perkembangannya rata-rata arus kas pendanaan yang dikeluarkan PT. CITACONTRAC selama tahun 2010-2017 masih menunjukkan angka penurunan sebesar 7,58\%. Dari Tabel diatas tersebut maka dapat dibuat grafik Arus Kas Pendanaan PT CITACONTRAC periode

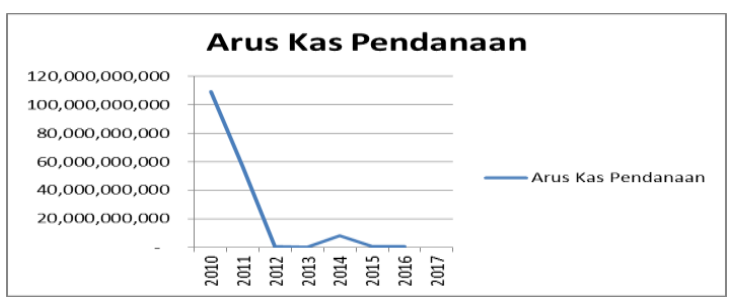

2010-2017:

Gambar 2. Arus kas pendanaan

Pada Grafik terlihat dengan jelas bahwa Arus Kas Pendanaan pada PT. CITACONTRAC menunjukkan angka penurunan semenjak tahun 2010 hingga tahun 2016. Penurunan Arus Kas Pendanaan paling tinggi terjadi pada tahun 2013 yaitu

Copyright (c) 2020 Mulia Rahmah, S. Kom., M.Si., Meliana Meliana

This work is licensed under a Creative Commons Attribution-NonCommercial-ShareAlike 4.0 International License. Page 101 
menurun sebesar Rp. 56.737.604.305 atau pertumbuhan sebesar minus $0,99 \%$ dari tahun 2012.

\section{Analisis Profitabilitas PT. CITACONTRAC}

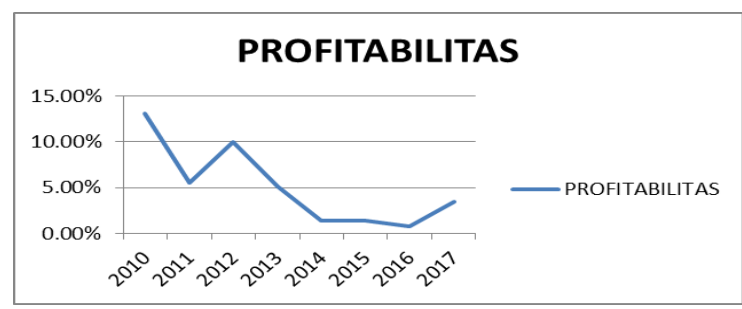

Profitabilitas pada penelitian ini diukur menggunakan return on assets, yaitu rasio laba setelah pajak dibagi total assets. Semakin besar return on assets menunjukkan tingkat keuntungan yang dicapai perusahaan membesar/meningkat. Berikut perkembangan profitabilitas yang diperoleh PT. CITACONTRAC selama periode tahun 2010-2016:

Tabel 3. Perkembangan profitabilitas tahun 2010-2016

\begin{tabular}{|c|c|c|c|c|}
\hline \begin{tabular}{|l|} 
Tahu \\
$\mathrm{n}$
\end{tabular} & $\begin{array}{l}\text { Net } \\
\text { Income(Rupiah }\end{array}$ & Total Assets & ROA & $\begin{array}{l}\text { Perkembanga } \\
\mathrm{n}\end{array}$ \\
\hline 2010 & $12,848,115,938$ & $98,206,729,923$ & $\begin{array}{l}13.08 \\
\%\end{array}$ & - \\
\hline 2011 & $11,929,496,483$ & $\begin{array}{l}217,226,948,48 \\
2\end{array}$ & $5.49 \%$ & $-7.59 \%$ \\
\hline 2012 & $15,313,375,545$ & $\begin{array}{l}153,140,038,19 \\
2\end{array}$ & $\begin{array}{l}10.00 \\
\%\end{array}$ & $4.51 \%$ \\
\hline 2013 & $8,515,873,751$ & $\begin{array}{l}165,806,100,76 \\
4\end{array}$ & $5.14 \%$ & $-4.86 \%$ \\
\hline 2014 & $2,050,107,356$ & $\begin{array}{l}150,309,585,59 \\
8\end{array}$ & $1.36 \%$ & $-3.77 \%$ \\
\hline 2015 & $\mid 1,947,005,767$ & $\begin{array}{l}136,880,491,33 \\
6\end{array}$ & $1.42 \%$ & $0.06 \%$ \\
\hline 2016 & $1,003,203,963$ & $\begin{array}{l}138,896,888,28 \\
7\end{array}$ & $0.72 \%$ & $0.70 \%$ \\
\hline 2017 & $4,666,379,238$ & $\begin{array}{l}134,889,988,76 \\
8\end{array}$ & $3.46 \%$ & $-2.74 \%$ \\
\hline \multicolumn{3}{|c|}{ Rata-rata } & $5.08 \%$ & $-1.96 \%$ \\
\hline
\end{tabular}

2016. Dilhat dari tabel 4.3 ROA tertinggi terjadi pada tahun 2010 yaitu $13.08 \%$ diperoleh dari net income sebesar 12.848.115.938 dibagi dengan total assets 98.206.729.923 dan ROA terendah terjadi di tahun 2016 yaitu $0.72 \%$ diperoleh dari net income sebesar 1.003.203.963 dibagi dengan total assets sebesr 138.896.888.287. Secara visual perkembangan profitabilitas pada PT. CITACONTRAC dapat dilihat pada grafik berikut :

Gambar 3. Perkembangan profitabilitas

Pada grafik terlihat return on assets tertinggi yang diperoleh PT. CITACONTRAC pada tahun 2010, yaitu mencapai $13,08 \%$, sebaliknya return on assets terendah terjadi pada tahun 2016, yaitu hanya mencapai $0.72 \%$. Semakin besar return on assets, berarti semakin besar tingkat keuntungan yang dicapai perusahaan sehingga kemungkinan suatu perusahaan.

\section{Analisis Hasil Penelitian dan Pembahasan}

Berikut disajikan Tabel berisi data time series yang akan diuji, namun sebelum diuji asumsi klasik dan diregres biaya operasional dan arus kas pendanaan terlebih dahulu di interpolasi menjadi data kuartal kemudian ditransform ke skala ratio oleh karena data tersebut masih merupakan data nominal:

PT. CITACONTRAC fluktuatif menurun dari tahun 2013 hingga tahun

Copyright (c) 2020 Mulia Rahmah, S. Kom., M.Si., Meliana Meliana

This work is licensed under a Creative Commons Attribution-NonCommercial-ShareAlike 4.0 International License. $\quad$ Page 102 
Tabel 4. Transformasi data biaya operasional dan arus kas pendanaan ke skala ratio

\section{Hasil Uji Asumsi Klasik}

\section{Hasil Uji Normalitas}

Uji normalitas digunakan untuk mengetahui apakah residual berdistribusi normal atau tidak, Salah satu cara untuk mendeteksi adalah dengan menganalisis grafik histogram dan normal probability plot. Berikut ini grafik histogram dan normal probability plot. Pada penelitian ini digunakan uji satu sampel KolmogorovSmirnov untuk menguji normalitas model regressi.

Tabel 5. Hasil Pengujian Asumsi Normalitas One-Sample Kolmogorov-Smirnov Test

\begin{tabular}{|c|c|c|c|}
\hline & BOP1 & AKP1 & ROA \\
\hline $\mathrm{N}$ & 32 & 32 & 32 \\
\hline Mean & 22.0284 & 20.2559 & 5.2541 \\
\hline Normal & & & \\
\hline Parametersa,b & & & \\
\hline Std. Deviation & .34274 & 2.65592 & 4.83238 \\
\hline Absolute & .135 & .186 & .164 \\
\hline Extreme & .135 & .186 & .159 \\
\hline Differences & & & \\
\hline Positive & & & \\
\hline Negative & -.135 & -.135 & -.164 \\
\hline $\begin{array}{l}\text { Kolmogorov- } \\
\text { Smirnov Z }\end{array}$ & .764 & 1.052 & .929 \\
\hline $\begin{array}{l}\text { Asymp. Sig. } \\
\text { tailed) }\end{array}$ & .604 & .218 & .355 \\
\hline
\end{tabular}

Gambar 4. Hasil Uji Normalitas Dengan Menggunakan Grafik Histogram

Berdasarkan gambar grafik histogram diatas maka menunjukkan bahwa data berdistribusi normal dan grafik menunjukkan distribusi yang tidak miring ke kanan atau ke kiri (skewness).

Grafik histogram terbentuk dengan

\begin{tabular}{|c|c|c|c|c|c|c|}
\hline \multirow{2}{*}{$\begin{array}{l}\text { Tahu } \\
\mathrm{n}\end{array}$} & \multirow{2}{*}{ Period } & \multirow{2}{*}{$\begin{array}{l}\text { Biaya } \\
\text { Operasional } \\
(\mathrm{X} 1)\end{array}$} & \multirow{2}{*}{ BOP(Ratio } & \multirow{2}{*}{$\begin{array}{l}\text { Arus Kas } \\
\text { Pendanaan } \\
\text { (X2) }\end{array}$} & \multirow{2}{*}{ AKP(Ratio } & \multirow{2}{*}{ ROA(Ratio } \\
\hline & & & & & & \\
\hline \multirow{4}{*}{2010} & Q1 & $\begin{array}{l}4,937,589,99 \\
6\end{array}$ & 22.32 & $3,877,655,529$ & 22.08 & 9.33 \\
\hline & $\mathrm{Q} 2$ & $\begin{array}{l}2,745,777,87 \\
8\end{array}$ & 21.73 & $2,888,988,237$ & 21.78 & 14.77 \\
\hline & Q3 & $\begin{array}{l}1,812,878,65 \\
5\end{array}$ & 21.32 & $3,877,655,421$ & 22.08 & 11.12 \\
\hline & Q4 & $\begin{array}{l}3,833,113,36 \\
0\end{array}$ & 22.07 & $3,817,657,701$ & 22.06 & 20.28 \\
\hline \multirow{4}{*}{2011} & Q1 & $\begin{array}{l}2,667,889,26 \\
6\end{array}$ & 21.7 & \begin{tabular}{|l}
$23,029,544,23$ \\
3
\end{tabular} & 23.86 & 4.12 \\
\hline & $\mathrm{Q} 2$ & $\begin{array}{l}3,877,654,23 \\
3\end{array}$ & 22.08 & $\begin{array}{l}32,088,630,26 \\
0\end{array}$ & 24.19 & 5.47 \\
\hline & Q3 & $\begin{array}{l}3,877,096,54 \\
4\end{array}$ & 22.08 & $\begin{array}{l}34,877,980,66 \\
2\end{array}$ & 24.28 & 6.60 \\
\hline & $\mathrm{Q} 4$ & $\begin{array}{l}3,654,391,34 \\
4\end{array}$ & 22.02 & $\begin{array}{l}19,333,344,43 \\
6\end{array}$ & 23.69 & 5.69 \\
\hline \multirow{4}{*}{2012} & Q1 & $\begin{array}{l}6,676,589,65 \\
4\end{array}$ & 22.62 & $\begin{array}{l}14,045,889,65 \\
5\end{array}$ & 23.37 & 8.82 \\
\hline & $\mathrm{Q} 2$ & $\begin{array}{l}5,754,688,89 \\
2\end{array}$ & 22.47 & $\begin{array}{l}11,020,789,65 \\
5\end{array}$ & 23.12 & 8.23 \\
\hline & Q3 & $\begin{array}{l}3,804,931,55 \\
6\end{array}$ & 22.06 & $8,776,554,355$ & 22.9 & 13.58 \\
\hline & $\mathrm{Q} 4$ & $\begin{array}{l}4,770,844,65 \\
4\end{array}$ & 22.29 & $\begin{array}{l}23,180,164,87 \\
1\end{array}$ & 23.87 & 9.60 \\
\hline \multirow{4}{*}{2013} & Q1 & $\begin{array}{l}3,879,665,43 \\
3\end{array}$ & 22.08 & $176,655,445$ & 18.99 & 5.38 \\
\hline & $\mathrm{Q} 2$ & $\begin{array}{l}4,756,877,08 \\
9\end{array}$ & 22.28 & $86,654,332$ & 18.28 & 6.86 \\
\hline & Q3 & $\begin{array}{l}4,866,789,23 \\
4\end{array}$ & 22.31 & $10,989,766$ & 16.21 & 8.66 \\
\hline & $\mathrm{Q} 4$ & $\begin{array}{l}2,637,380,34 \\
4\end{array}$ & 21.69 & $11,494,688$ & 16.26 & 1.88 \\
\hline \multirow{4}{*}{2014} & Q1 & $\begin{array}{l}4,877,289,75 \\
6\end{array}$ & 22.31 & $21,080,988$ & 16.86 & 1.32 \\
\hline & $\mathrm{Q} 2$ & $\begin{array}{l}4,877,896,54 \\
6\end{array}$ & 22.31 & $103,255,611$ & 18.45 & 1.96 \\
\hline & Q3 & $\begin{array}{l}2,567,866,54 \\
4\end{array}$ & 21.67 & $16,818,159$ & 16.64 & 1.20 \\
\hline & $\mathrm{Q} 4$ & $\begin{array}{l}1,918,210,05 \\
0\end{array}$ & 21.37 & $24,037,616$ & 17 & 1.02 \\
\hline \multirow{4}{*}{2015} & Q1 & $\begin{array}{l}3,455,678,92 \\
1\end{array}$ & 21.96 & $1,285,096,195$ & 20.97 & 1.43 \\
\hline & $\mathrm{Q} 2$ & $\begin{array}{l}4,899,456,78 \\
9\end{array}$ & 22.31 & $1,962,887,658$ & 21.4 & 1.83 \\
\hline & Q3 & $\begin{array}{l}3,332,869,89 \\
6\end{array}$ & 21.93 & $1,989,878,977$ & 21.41 & 1.30 \\
\hline & $\mathrm{Q} 4$ & $\begin{array}{l}1,476,088,49 \\
9\end{array}$ & 21.11 & $2,999,905,678$ & 21.82 & 0.98 \\
\hline \multirow{4}{*}{2017} & Q1 & $\begin{array}{l}4,544,867,55 \\
6\end{array}$ & 22.24 & $85,055,245$ & 18.26 & 0.77 \\
\hline & $\mathrm{Q} 2$ & $\begin{array}{l}4,442,558,75 \\
5\end{array}$ & 22.21 & $68,886,788$ & 18.05 & 0.80 \\
\hline & Q3 & $\begin{array}{l}3,088,765,62 \\
2\end{array}$ & 21.85 & $75,055,655$ & 18.13 & 0.76 \\
\hline & $\mathrm{Q} 4$ & $\begin{array}{l}2,954,522,82 \\
6\end{array}$ & 21.81 & $74,217,153$ & 18.12 & 0.53 \\
\hline \multirow{4}{*}{2018} & Q1 & $\begin{array}{l}4,865,455,89 \\
8\end{array}$ & 22.31 & $98,896,543$ & 18.41 & 2.85 \\
\hline & $\mathrm{Q} 2$ & $\begin{array}{l}3,889,265,88 \\
4\end{array}$ & 22.08 & $98,688,655$ & 18.41 & 3.85 \\
\hline & Q3 & $\begin{array}{l}4,877,889,26 \\
0\end{array}$ & 22.31 & $109,168,004$ & 18.51 & 2.85 \\
\hline & $\mathrm{Q} 4$ & $3,607,983,49$ & 22.01 & $135,889,088$ & 18.73 & 4.29 \\
\hline
\end{tabular}

Copyright (c) 2020 Mulia Rahmah, S. Kom., M.Si., Meliana Meliana 
kecil atau sama dengan 0.10. Kemudian pengambilan keputusan melihat hasil nilai Variance Inflation Factor (VIF) jika tidak terjadi multikolinieritas, nilai VIF lebih kecil dari 10,00 dan jika terjadi multikolinieritas, nilai VIF lebih besar atau sama dengan 10,00. Adapun hasil uji multikolinieritas dalam penelitian ini adalah sebagai berikut:

merata, sehingga grafik histogram menunjukkan bahwa residual terdistribusi normal dan memenuhi asumsi normalitas. Adapun hasil perhitungan uji normalitas jika melihat dari segi grafik yang ditunjukkan pada gambar grafik p-p plot berikut :

Gambar 5. Grafik p-p plot

Pada grafik normal p-plot menunjukkan bahwa titik-titik (data) menyebar disekitar garis regional serta penyebarannya mengikuti arah garis regional, maka dapat disimpulkan bahwa data yang diolah merupakan data yang berdistibusi normal sehingga uji normalitas terpenuhi

\section{Hasil Uji Multikolinieritas}

Uji multikolinieritas digunakan untuk mengetahui apakah pada model regresi ditemukan adanya korelasi antar variabel independen (variabel bebas). Multikolinieritas dapat dideteksi dari nilai tolerance dan Variance Inflation Factor (VIF) pada model regresi. Pengambilan keputusan melihat hasil nilai tolerance jika tidak terjadi multikolinieritas, jika nilai tolerance lebih besar 0,10 dan juga jika terjadi multikolinieritas, nilai tolerance lebih
Tabel 6. Uji Multikolinieritas

\begin{tabular}{|l|l|l|}
\hline \multirow{2}{*}{ Model } & \multicolumn{2}{|l|}{ Collinearity Statistics } \\
\cline { 2 - 3 } & Tolerance & VIF \\
\hline 1 & & \\
(Constant) & & 1.003 \\
\hline BOP 1 & .997 & 1.003 \\
\hline AKP 1 & .997 & \\
\hline
\end{tabular}

Dari Tabel diatas, maka dapat diketahui bahwa hasil nilai tolerance untuk variabel biaya operasional (X1) dan arus kas pendanaan (X2) sebesar 0,997 lebih besar

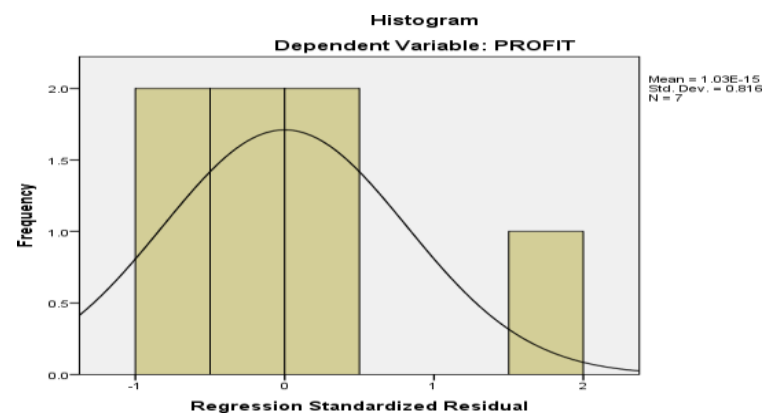

dari 0,10. Sementara, nilai VIF untuk variabel biaya operasional (X1) dan arus kas pendanaan (X2) sebesar 1,003 lebih kecil dari 10,00. Maka mengacu pada dasar pengambilan keputusan dalam uji multikolinieritas dapat disimpulkan bahwa tidak terjadi gejala multikolinieritas dalam model regresi.

\section{Hasil Uji Heterokedastisitas}

Uji heterokedastistas digunakan untuk mengetahui ada atau tidaknya ketidaksamaan variance dari residual pada

Copyright (c) 2020 Mulia Rahmah, S. Kom., M.Si., Meliana Meliana 


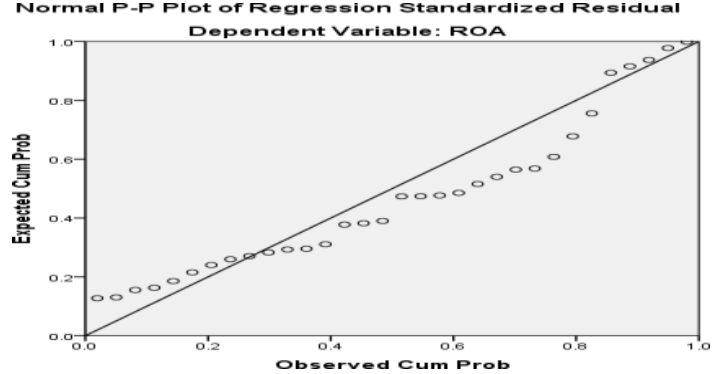

model regresi. Berdasarkan hasil data yang telah diolah, maka hasil scatterplot dapat dilihat pada gambar sebagai berikut:

Gambar 6. Uji heterokedasitas

Pada grafik scatterplot diatas, terlihat bahwa titik-titik menyebar secara acak dan tersebar baik diatas maupun dibawah angka 0 pada

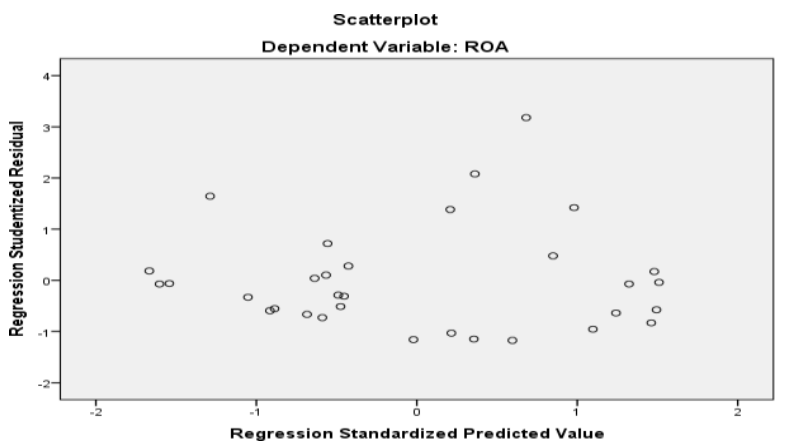

sumbu Y. Hal ini menunjukkan bahwa tidak terjadi heterokedastisitas pada model regresi

\section{Hasil Uji Hipotesis}

\section{Hasil Uji Regresi Linier Berganda}

Regresi linier berganda digunakan untuk mengetahui hubungan antara variabel independen dengan variabel dependen, apakah masing-masing independen berhubungan positif atau negatif, dalam penelitian ini variabel independen yaitu biaya operasional (X1), arus kas pendanaan (X2) dan variabel dependen yaitu profitabilitas (Y). Adapun hasil uji regresi linier berganda adalah sebagai berikut

Tabel 7. Uji Linier berganda

\begin{tabular}{|l|l|l|l|l|l|}
\hline Mode & $\begin{array}{l}\text { Unstandar } \\
\text { dized } \\
\text { Coefficien } \\
\text { ts }\end{array}$ & $\begin{array}{l}\text { Standar } \\
\text { dize d } \\
\text { Coeffici } \\
\text { ents }\end{array}$ & thig. & $\begin{array}{l}\text { Collinear } \\
\text { ity } \\
\text { Statistics }\end{array}$ \\
\hline
\end{tabular}

ISSN : 2406-7415

e-ISSN : 2655-9919

JURNAL AKUNTANSI DAN BISNIS KRISNADWIPAYANA

\begin{tabular}{|c|c|c|c|c|c|c|}
\hline & B & $\begin{array}{l}\text { Vol. } 7 \text { No } \\
\text { Std. } \\
\text { Error }\end{array}$ & $\frac{2(\mathrm{~N}}{\mathrm{Be}}$ & Iei - & & $\begin{array}{l}\text { us) } 202( \\
\begin{array}{l}\text { Toler } \\
\text { anc e }\end{array}\end{array}$ \\
\hline $\begin{array}{l}(\text { Cons } \\
\tan t)\end{array}$ & -47.699 & 49.711 & & $\begin{array}{l}.96 \\
0\end{array}$ & $\begin{array}{l}3 \\
45\end{array}$ & \\
\hline $\begin{array}{l}1 \\
\text { BOP1 }\end{array}$ & 1.581 & 2.255 & .11 & $\mid \begin{array}{l}70 \\
1\end{array}$ & $\begin{array}{l}4 \\
89\end{array}$ & .997 \\
\hline $\mathrm{AKP} 1$ & .895 & .291 & 2 & $\begin{array}{l}3.0 \\
77\end{array}$ & 05 & .997 \\
\hline
\end{tabular}

Dari tabel diatas dibentuk persamaan linier sebagai berikut :

$\mathrm{Y}=(47.699)+1.581 \mathrm{X} 1+0,895 \mathrm{X} 2$

Dimana :

Y: Profitabilitas

$\mathrm{X} 1$ : Biaya Operasional

$\mathrm{X} 2$ : Arus Kas Pendanaan

Koefisien yang terdapat pada persamaan diatas dapat dijelaskan sebagai berikut :

Konstanta sebesar (47.699) artinya jika biaya operasional (X1) dan arus kas pendanaan (X2) nilainya adalah 0 , maka Profitabilitas (Y) nilainya adalah minus 47.699. Biaya Operasional memiliki koefisien bertanda positif sebesar 1.581, artinya setiap kenaikan biaya operasional sebesar 1 satuan rupiah diprediksi akan menaikkan profitabilitas sebesar 1.581.Arus Kas dari aktivitas pendanaan memiliki koefisien bertanda positif sebesar 0,895, artinya setiap kenaikan arus kas aktivitas pendanaan sebesar 1 satuan rupiah diprediksi akan menaikan profitabilitas sebesar 0,895

\section{Hasil Uji Koefisien Determinasi (R2)}

Koefisien determinasi digunakan untuk melihat seberapa besar variabel biaya operasional dan arus kas aktivitas pendanaan secara bersama-sama berpengaruh terhadap profitabilitas.

Copyright (c) 2020 Mulia Rahmah, S. Kom., M.Si., Meliana Meliana 
Tabel 8. Uji R2

\begin{tabular}{|l|l|l|l|l|l|}
\hline $\begin{array}{l}\text { Mode } \\
1\end{array}$ & $\begin{array}{l}\text { R } \\
\text { Squar } \\
\text { e }\end{array}$ & $\begin{array}{l}\text { Adjuste } \\
\text { d } r\end{array}$ & $\begin{array}{l}\text { Std. } \\
\text { Square } \\
\text { Sqror of } \\
\text { the } \\
\text { Estimat } \\
\text { e }\end{array}$ & Wurbin \\
\hline 1 & $\begin{array}{l}.510 \\
\text { a }\end{array}$ & .260 & .209 & 4.29653 & 1.072 \\
\hline
\end{tabular}

Berdasarkan tabel output di atas (lihat Tabel) diketahui nilai koefisien determinasi atau $\mathrm{R}$ Square adalah sebesar 0,260. Nilai R Square ini didapat dari hasil kuadrat dari 0,510. Besarnya angka koefisien determinasi atau $\mathrm{R}$ Square adalah 0,260 atau sama dengan 26,0\%. Angka tersebut mengandung arti bahwa biaya operasional dan arus kas pendanaan berpengaruh terhadap profitabilitas sebesar $26,0 \%$. Sedangkan sisanya sebesar $74,0 \%$ dipengaruhi oleh variabel lainnya atau variabel yang tidak diteliti.

\section{Hasil Uji Secara Parsial (Uji Statistik t)}

Uji statistik digunakan untuk mengetahui apakah variabel independen secara parsial (individual) berpengaruh secara signifikan terhadap variabel dependen. Untuk mengetahui pengaruh variabel independen secara parsial (individual) terhadap variabel dependen dapat dilihat pada tingkat signifikan yaitu 0,05. Jika nilai profitabilitas lebih kecil dari 0,05, maka Ha diterima dan Ho ditolak, sedangkan jika nilai profitabilitas lebih besar dari 0,05 maka Ho diterima dan Ha ditolak. Berikut ini hasil uji statistik t dari variabel independen yang akan diuraikan sebagai berikut:

\section{A. Hasil uji pengaruh Biaya operasional terhadap Profitabilitas}

Tabel 9. Hasil uji statistik t untuk variabel biaya operasional terhadap profitabilitas

\begin{tabular}{|c|c|c|c|c|c|c|c|}
\hline \multirow[t]{2}{*}{ Model } & \multicolumn{3}{|c|}{$\begin{array}{l}\text { Unstandardize } \\
\text { d Coefficients }\end{array}$} & \multicolumn{2}{|c|}{\begin{tabular}{|l|} 
Standardiz \\
ed \\
Coefficient \\
s
\end{tabular}} & \multirow{2}{*}{\multicolumn{2}{|c|}{ Sig }} \\
\hline & \multicolumn{2}{|l|}{$\mathrm{BB}$} & \begin{tabular}{|l} 
Std. \\
Error
\end{tabular} & \multicolumn{2}{|l|}{ Beta } & & \\
\hline \multirow[t]{2}{*}{$\begin{array}{l}\text { (Constan } \\
\text { t) }\end{array}$} & \multicolumn{3}{|c|}{$-\left.37.618\right|_{8} ^{56.16}$} & \multirow{2}{*}{\multicolumn{2}{|c|}{.138}} & \multicolumn{2}{|l|}{67} \\
\hline & \multicolumn{2}{|c|}{1.946} & 2.55 & & & $\begin{array}{l}.76 \\
3\end{array}$ & .4 \\
\hline Model & \begin{tabular}{|l|l|}
$\mathrm{R}$ & $\mathrm{R}$ \\
& Squar \\
$\mathrm{e}$
\end{tabular} & \multicolumn{2}{|c|}{ R } & \multicolumn{4}{|c|}{\begin{tabular}{|l|l} 
Adjusted & Std. Error of \\
$\mathrm{R}$ & the Estimate \\
Square & \\
\end{tabular}} \\
\hline 1 & $\begin{array}{l}138 \\
\mathrm{a}\end{array}$ & \multicolumn{2}{|c|}{.019} & .014 & \multicolumn{2}{|c|}{4.8652} & \\
\hline
\end{tabular}

Berdasarkan tabel coefficients diatas menunjukkan nilai $\mathrm{t}$ pada variabel biaya operasional sebesar 0,763 dengan nilai signifikansi 0,451 . Nilai thitung selanjutnya dikonsultasikan dengan nilai ttabel yang didasarkan pada (df) n-2 atau 32- 2=30 dan taraf kesalahannya $=5 \%$. Maka diperoleh nilai ttabel sebesar 1.697 . Sehingga hasil menunjukkan bahwa thitung lebih kecil dari ttabel yakni $0,763<1.697$.

$\mathrm{Y}=(37.618)+1.946$

Dari hasil uji koefisien determinasi di atas menunjukkan bahwa nilai $\mathrm{R}$ Square adalah 0,019. Hal ini berarti hanya sebesar $0,19 \%$ yang kontribusi variabel profitabilitas. Dari persamaan di atas terlihat bahwa biaya operasional mempunyai pengaruh yang positif terhadap profitabilitas. Hubungan positif tersebut dapat dilihat pada tanda $(+)$ pada persamaan tersebut. Hubungan positif tersebut

Copyright (c) 2020 Mulia Rahmah, S. Kom., M.Si., Meliana Meliana 
menunjukkan bahwa profitabilitas akan searah atau sejalan dengan perubahan jumlah biaya operasional yang telah dikeluarkan oleh perusahaan.

\section{B. Hasil uji Arus Kas Pendanaan terhadap Profitabilitas}

Tabel 10. Hasil uji statistik t untuk arus kas pendanaan terhadap profitabilitas

\begin{tabular}{|c|c|c|c|c|c|}
\hline \multirow[t]{2}{*}{ Model } & \multicolumn{2}{|c|}{$\begin{array}{l}\text { Unstandardiz } \\
\text { ed } \\
\text { Coefficients }\end{array}$} & \multirow{2}{*}{\begin{tabular}{|l}
$\begin{array}{l}\text { Standardiz } \\
\text { ed } \\
\text { Coefficient } \\
\text { s }\end{array}$ \\
Beta
\end{tabular}} & & \multirow[t]{2}{*}{ Sig } \\
\hline & $\mathrm{B}$ & \begin{tabular}{|l|} 
Std. \\
Error
\end{tabular} & & & \\
\hline $\begin{array}{l}\text { (Constan } \\
\text { t) }\end{array}$ & $\begin{array}{l}13.09 \\
8\end{array}$ & 5.884 & 498 & $\begin{array}{l}-2.22 \\
6\end{array}$ & $\begin{array}{l}.03 \\
4\end{array}$ \\
\hline $\begin{array}{l}1 \\
\text { AKP1 }\end{array}$ & .906 & .288 & & $\begin{array}{l}3.14 \\
5\end{array}$ & $\begin{array}{l}.00 \\
4\end{array}$ \\
\hline
\end{tabular}

\begin{tabular}{|l|l|l|l|l|}
\hline Model & $\mathrm{R}$ & $\begin{array}{l}\mathrm{R} \\
\text { Square }\end{array}$ & $\begin{array}{l}\text { Adjusted R } \\
\text { Square }\end{array}$ & $\begin{array}{l}\text { Std. Error of } \\
\text { the Estimate }\end{array}$ \\
\hline 1 & $.498 \mathrm{a}$ & .248 & .223 & 4.25996 \\
\hline
\end{tabular}

Berdasarkan tabel coefficients diatas menunjukkan nilai t pada variabel arus kas pendanaan sebesar 3.145 dengan nilai signifikansi 0,004 . Nilai thitung selanjutnya dikonsultasikan dengan nilai ttabel yang didasarkan pada (df) $n-2$ atau 32-2=30 dan taraf kesalahannya $=5 \%$. Maka diperoleh nilai ttabel sebesar 1.697. Sehingga hasil menunjukkan bahwa thitung lebih besar dari ttabel yakni $3.145>1.697$. Dari hasil uji koefisien determinasi di atas menunjukkan bahwa nilai $\mathrm{R}$ Square adalah 0,248 . Hal ini berarti hanya sebesar $24,8 \%$ yang kontribusi variabel profitabilitas. Dari persamaan di atas terlihat bahwa arus kas pendanaan mempunyai pengaruh yang positif terhadap profitabilitas. Hubungan positif tersebut dapat dilihat pada tanda (+) pada persamaan tersebut. Hubungan positif tersebut menunjukkan bahwa profitabilitas akan searah atau sejalan dengan perubahan jumlah arus kas pendanaan. Artinya apabila terjadi kenaikan arus kas pendanaan maka meningkatkan profitabilitas di PT. CITACONTRAC.

\section{Hasil Uji Signifikan Simultan (Uji Statistik F)}

Uji F digunakan untuk mengetahui apakah variabel independen secara simultan (bersama-sama) berpengaruh secara signifikan terhadap variabel dependen. Untuk mengetahui ada tidaknya pengaruh variabel independen secara simultan (bersama-sama) terhadap variabel dependen dapat dilihat pada tingkat signifikan yaitu 0,05 . Jika nilai profitabilitas lebih kecil dari 0.05 maka Ha diterima dan Ho ditolak, sedangkan jika nilai profitabilitas lebih besar dari 0,05 maka Ho diterima dan Ha ditolak, Hasil uji F dapat dilihat sebagai berikut:

Tabel 11. Hasil uji statistik F untuk biaya operasional dan arus kas pendanaan terhadap profitabilitas

\begin{tabular}{|l|l|l|l|l|l|}
\hline Model & \multicolumn{2}{|l|}{$\begin{array}{l}\text { Sum of } \\
\text { Squares }\end{array}$} & $\begin{array}{l}\text { Mean } \\
\text { Square }\end{array}$ & F & Sig. \\
\hline Regression & 188.563 & 2 & 94.282 & $5.107 .013 b$ \\
1Residual & 535.345 & 29 & 18.460 & & \\
Total & 723.908 & 31 & & & \\
\hline
\end{tabular}

Copyright (c) 2020 Mulia Rahmah, S. Kom., M.Si., Meliana Meliana

This work is licensed under a Creative Commons Attribution-NonCommercial-ShareAlike 4.0 International License. Page 107 


\section{Pembahasan}

\section{Pengaruh Biaya Operasional Terhadap Profitabilitas}

Berdasarkan tabel coefficients diatas menunjukkan nilai $\mathrm{t}$ pada variabel biaya operasional sebesar 0,763 dengan nilai signifikansi 0,451 . Nilai thitung selanjutnya dikonsultasikan dengan nilai ttabel yang didasarkan pada (df) n-2 atau 32-2=30 dan taraf kesalahannya $=5 \%$. Maka diperoleh nilai ttabel sebesar 1.697. Sehingga hasil menunjukkan bahwa thitung lebih kecil dari ttabel yakni $0.763<1.697$ yang artinya tidak berpengaruh biaya operasional terhadap profitabilitas namun berdasarkan persamaan regresi linier sederhana yaitu $\mathrm{Y}=(37.618)+$ 1.946 yakni biaya operasional mempunyai pengaruh yang positif terhadap profitabilitas, artinya setiap peningkatan biaya operasional sebesar 1 satuan diprediksi akan akan meningkatkan profitabilitas sebesar 1.946 , Selain itu peningkatan profitabilitas ini tidak dapat diukur dalam segi biaya operasionalnya saja, akan tetapi juga secara menyeluruh termasuk dari kinerja organisasinya, Apabila kinerja organisasinya memuaskan maka profitabilitas perusahaan akan semakin meningkat, begitu pun sebaliknya apabila kinerja organisasinya kurang memuaskan maka profitabilitas perusahaan akan menurun

Hasil regresi menyatakan bahwa biaya operasional tidak berpengaruh terhadap profitabilitas, hal ini dapat dibuktikan bahwa biaya operasional mengalami rata-rata minus 4,42 dari tahun 2010 sampai 2017 tidak mempengaruhi laba di perusahaan. Dengan menurunnya biaya operasional diharapkan akan meningkatkan pula profitabilitas untuk kesejahteraan perusahaan.

Hasil Penelitian ini sesuai dengan penelitian yang dilakukan oleh Dian Pratiwi dalam penelitiannya yang berjudul " pengaruh analisis biaya operasional dan arus kas pendanaan terhadap profitabilitas" dengan menggunakan metode analisis kuantitatif dan kualitatif. Hasil penelitian menunjukkan bahwa biaya operasional tidak mempunyai pengaruh terhadap profitabilitas

\section{Pengaruh Arus Kas Pendanaan Terhadap Profitabilitas}

Dari penelitian yang dilakukan, diperoleh hasil berpengaruh arus kas pendanaan terhadap profitabilitas, dilihat berdasarkan dilihat berdasarkan nilai signifikan yang lebih dari 0,05 . Hal ini dapat dilihat dari hasil uji t yaitu thitung lebih besar dari ttabel yakni $3.145<1.697$ yang artinya berpengaruh arus kas pendanaan terhadap profitabilitas dan juga berdasarkan persamaan regresi linier sederhana yaitu $\mathrm{Y}=$ $(13.908)+906$ yakni arus kas pendanaan mempunyai pengaruh yang positif terhadap profitabilitas. Hubungan positif tersebut menunjukkan bahwa profitabilitas akan searah atau sejalan dengan perubahan jumlah arus kas pendanaan Artinya apabila terjadi kenaikan arus kas pendanaan maka meningkatkan profitabilitas di PT. CITACONTRAC karena dipengaruhi dari aktivitas operasi yaitu kegiatan utama dari perusahaan untuk menghasilkan pendapatan, dan secara langsung berhubungan dengan kas. Sebagian besar aktivitas operasi berasal dari penjualan produk atau jasa. Selain itu, pendapatan dari pembayaran kontrak dagang, royalti, komisi atau fee juga digolong kan pada aktivitas ini

Hasil regresi menyatakan bahwa arus kas pendanaan berpengaruh terhadap profitabilitas, hal ini dapat dibuktikan bahwa rata-rata arus kas pendanaan yang dikeluarkan PT. CITACONTRAC selama

Copyright (c) 2020 Mulia Rahmah, S. Kom., M.Si., Meliana Meliana

This work is licensed under a Creative Commons Attribution-NonCommercial-ShareAlike 4.0 International License. Page 108 
tahun 2010-2017 masih menunjukkan angka sebesar $8,76 \%$. Dengan meningkatnya dana yang masuk di aktivitas pendanaan diharapkan akan meningkatkan pula profitabilitas untuk kesejahteraan perusahaan.

Hasil Penelitian ini sesuai dengan penelitian yang dilakukan oleh Junaidi (2016) dalam penelitiannya yang berjudul “ pengaruh biaya operasional dan arus kas terhadap profitabilitas pada UD Sari Bumi Probolinggo" dengan menggunakan metode analisis Analisis Regresi Linier Berganda dan Analisis Korelasi Berganda. Hasil penelitian menunjukkan bahwa arus kas pendanaan mempunyai pengaruh terhadap profitabilitas. Pengaruh Biaya Operasional dan Arus Kas Pendanaan Terhadap Profitabilitas

Dari penelitian yang dilakukan, diperoleh hasil biaya operasional dan arus kas pendanaan secara simultan (bersamasama) tidak berpengaruh terhadap profitabilitas dengan berdasarkan nilai signifikan yang lebih dari 0,05 . Hal ini dapat dilihat dari $\mathrm{F}$ hitung lebih kecil dari $\mathrm{F}$ Tabel ( $3.327<5.107$ ). Artinya secara bersamasama biaya operasional dan arus kas pendananaan tidak berpengaruh terhadap profitabilitas. Hal ini dikarenakan pada kaitannya untuk mendapatkan laba suatu perusahaan perlu menyusun dan merencanakan anggaran serta melaporkan hasil kinerja perusahaan, baik itu dalam bentuk laporan arus kas, laporan laba rugi, maupun neraca. Hal ini diperlukan agar pimpinan dapat melakukan evaluasi kinerja apabila ditemukan adanya penyimpangan atau keuangan perusahaan tidak sehat. Sehingga dalam prakteknya baik biaya operasional, dan arus kas operasi akan sangat berperan dalam menghasilkan profitabilitas bagi perusahaan

\section{KESIMPULAN DAN SARAN}

\section{Kesimpulan}

Berdasarkan hasil penelitian dan analisis data mengenai analisis pengaruh biaya operasional dan arus kas pendanaan terhadap profitabilitas pada PT. CITACONTRAC. Maka pada bagian akhir dari penelitian ini penulis menarik kesimpulan sekaligus memberikan saran sebagai berikut :

1. Hasil uji secara parsial biaya operasional (X1) Berdasarkan tabel coefficients diatas menunjukkan nilai t pada variabel biaya operasional sebesar 0,763 dengan nilai signifikansi 0,451 . Nilai thitung selanjutnya dikonsultasikan dengan nilai ttabel yang didasarkan pada (df) n-2 atau $32-2=30$ dan taraf kesalahannya $=5 \%$. Maka diperoleh nilai ttabel sebesar 1.697. Sehingga hasil menunjukkan bahwa thitung lebih kecil dari ttabel yakni $0.763<1.697$ yang artinya tidak berpengaruh biaya operasional terhadap profitabilitas namun berdasarkan persamaan regresi linier sederhana yaitu $\mathrm{Y}=(37.618)+1.946$ yakni biaya operasional mempunyai pengaruh yang positif terhadap profitabilitas. Hubungan positif tersebut dapat dilihat pada tanda (+) pada persamaan tersebut.

2. Hasil uji secara parsial arus kas pendanaan (X2) berpengaruh signifikan terhadap profitabilitas (Y) pada PT. CITACONTRAC. Hal ini disebabkan hasil menunjukkan bahwa thitung lebih besar dari ttabel yakni $3.145<1.697$ yang artinya berpengaruh arus kas pendanaan terhadap profitabilitas dan juga berdasarkan persamaan regresi

Copyright (c) 2020 Mulia Rahmah, S. Kom., M.Si., Meliana Meliana 
linier sederhana yaitu $\mathrm{Y}=(13.908)+906$ $\mathrm{X} 2$ yakni arus kas pendanaan mempunyai pengaruh yang positif terhadap profitabilitas. Hubungan positif tersebut dapat dilihat pada tanda $(+)$ pada persamaan tersebut.

3. Hasil uji secara simultan biaya operasional (X1) dan arus kas pendanaan (X2) tidak pengaruh signifikan terhadap profitabilitas (Y), Hal ini disebabkan $\mathrm{F}$ hitung sebesar 1.218 jika dibadingkan dengan $\mathrm{F}$ Tabel sebesar 6.944 yang didapat dari $(\mathrm{DK}=\mathrm{n}-\mathrm{k}-1 ;=7-2-1=$ 4), maka $F$ hitung lebih kecil dari $F$ Tabel ( $3.327<5.107)$. Artinya secara bersama-sama biaya operasional dan arus kas pendananaan tidak berpengaruh terhadap profitabilitas

\section{SARAN}

Sebagai masukan dalam upaya peningkatan Biaya Operasional dan Arus Kas Pendanaan terhadap Profitabilitas, maka disarankan sebagai berikut:

1. Bagi Perusahaan

a. Akan lebih efisien bila perusahaan dapat berhemat dalam menggunakan dan mengalokasikan biaya operasional yang cenderung mengalami kenaikan dan penurunan setiap tahunnya, yaitu dengan cara menghemat pengeluaran untuk biaya opersional dengan menekan anggaran biaya operasional

b. Walaupun kondisi arus kas pendanaan yang masih fluktuatif, namun PT.CITACONTRAC harus memperhatikan upaya dan strategi yang dapat meningkatkan minat kerja sama sebagai vendor PLN karena arus kas merupakan sumber informasi untuk menilai kemampuan perusahaan dalam mengalokasiakan dana kasnya.

c. Profitabilitas perusahaan mengalami penurunan, perusahaan diharapkan dapat meningkatkan laba setiap tahunnya dengan cara meningkatkan perolehan hasil pekerjaan disetiap proyek pada PT. CITACONTRAC.

2. Bagi Peneliti

Untuk penelitian selanjutnya, variabel bebas yang digunakan hendaknya tidak hanya biaya operasional dan arus kas saja karena masih banyak faktor pada perusahaan yang dapat mempengaruhi profitabilitas seperti pengelolaan piutang, pengelolaan hutang dan lain sebagainya. Selain itu, jumlah sampel dan perusahaan yang diteliti sebaiknya diperbanyak untuk memperkuat hasil penelitian.

\section{DAFTAR PUSTAKA}

Attin \& Nurchayati. (2015). Pengaruh Arus Kas Operasi Dan Likuiditas Terhadap Profitabilitas (STUDI EMPIRIS PADA PERUSAHAAN PROPERTY DAN REAL ESTATE YANG TERDAFTAR DI BEI), Jurnal, Semarang : Universitas 17 Agustus 1945

Bhuono, Agung Nugroho. (2005). Strategi Jitu Memilih Metode Statistik Penelitian dengan SPSS. Yogyakarta : Penerbit Andi

CT Hongren, SM Datar, \& G Foster (2005). Akuntansi Biaya: Pendekatan

Copyright (c) 2020 Mulia Rahmah, S. Kom., M.Si., Meliana Meliana 
Manajerial, Edisi Kesebelas, Jakarta : Indeks

Dwi Martani. (2012). Keuangan Menengah Berbasis PSAK, Buku 1, Jakarta : Salemba Empat

Ghozali, Imam. (2007). Analisis Multivariate Dengan Program SPSS, Cetakan Empat, Semarang : Badan Penerbit Universitas Diponegoro

Gujarati, N Damodar. (2012). Dasar-dasar Ekonometrika, Jilid kelima, Jakarta : Erlangga

Harahap, Sofyan Syafri. (2011). Analisis Kritis Atas Laporan Keuangan, Jakarta: Raja Garfindo Persada

Hartoko, Alfa. (2011). Menyusun Laporan Keuangan Untuk Usaha, Cetakan ke 1, Yogyakarta : Multicom (Ikatan Ikapi)

Hasan, M Iqbal. (2001). Statistik Inferensial Jakarta, Jakarta : Bumi AksaraHorne, James C

Van dan Wachowiczr. (2012) Prinsipprinsip Manajemen Keuangan (Edisi 13), Jakarta : Salemba Empat

Jopie dan Jusuf. (2007). Analisis Kredit Untuk Account Officer: Cetakan ke 8, PT. Jakarta : Gramedia Pustaka Utama Junaidi. (2016). Pengaruh Biaya Operasional dan Arus Kas terhadap Profitabilitas pada UD Sari Bumi Probolinggo, Jurnal, Probolinggo: Universitas Panca Marga

Kasmir. (2014). Analisis Laporan Keuangan, cetakan ke-7, Jakarta : PT. Raja Grafindo Persada

Kuswadi. 2005. Meningkatkan Laba Melalui Pendekatan Akuntansi Keuangan dan
JURNAL AKUNTANSI DAN BISNIS KRISNADWIPAYANA Vol. 7 No. 2 (Mei - Agustus) 2020 Akuntansi Biaya, Edisi ke satu, Jakarta: PT Elex Media Komputindo Kelompok Gramedia Anggota IKAPI

Lukman Syamsudin. (2009). Manajemen Keuangan Perusahaan: Konsep Aplikasi dalam Perencanaan, Pengawasan, dan Pengembalian Keputusan (Edisi Baru), Jakarta : PT Raja Grafindo Persada

Mariati, Tinneke, dan Henny. (2016). Analisis Biaya Operasional dan Arus Kas Terhadap Profitabilitas pada PT. JASA RAHARJA (PERSERO) CABANG MANADO, Jurnal Administrasi Bisnis : Universitas Manado

Usman Ali. (2015). Pengaruh Arus Kas Operasi dan Likuiditas terhadap Profitabilitas, Jurnal Ilmiah UNTAG : Semarang

Mulyadi. (2012). Akuntansi Biaya, Cetakan kedua, Universitas Gajah Mada : UPP STIM YKPN

Soemarso. (2010). Akuntansi Suatu Pengantar, Edisi kelima, Buku 2, Jakarta : Salemba Empat

Sundjaja Ridwan, \& Inge Barlian. (2003). Manajemen Keuangan I , Edisi keempat, Jakarta : Prenhallindo

Supriyono. (2000). Akuntansi Biaya : Perencanaan dan Pengendalian Biaya serta Pembuatan Keputusan, Edisi Kedua, Yogyakarta : BPFE

Weygandt. (2008). Pengantar Akuntansi, Edisi ketujuh, Buku Dua, Jakarta : Salemba Empat 